\title{
O SILÊNCIO DE FOUCAULT PARA O ALCEBÍADES DE PLUTARCO
}

\author{
Tereza Virgínia Ribeiro Barbosa ${ }^{\star}$ \\ Universidade Federal de Minas Gerais
}

\begin{abstract}
We intend to relate Plutarch and Foucault through a character present in the work of both thinkers, namely, Alcibiades, the engenés. A comparison between the two representations shows that the focus of interest differs in each case. Our reflection is based on the following questions: Why doesn't Foucault discuss Plutarch's Alcibiades in The Hermeneutics of the Subject? Would it be because, unlike Plato, the Greek moralist reveals the aristocrat as a failure, as the result of a mistaken pedagogical choice or as the portrait of his community?
\end{abstract}

KEYWORDS: Plutarch; Foucault; Alcibiades; pedagogical choices, biography.

D. e saída, antecipo que Michel Foucault, para nós, será tão somente um pretexto. Não poderíamos falar de Foucault ele mesmo; não o conhecemos para tanto, nem pessoalmente nem pela leitura de toda a sua vasta produção. Por outro lado, como, desde sempre, estivemos e estamos preocupados com a educação dos jovens, Plutarco, embora também não seja nossa especialidade, é quase uma meta perene. Desse modo, fique claro que não nos ocuparemos exclusivamente nem de Foucault, nem de Plutarco; mas refletiremos, espero, com a ajuda de ambos (e, subjacente a essa presença, também com o filósofo italiano Giorgio Agamben no ensaio "O que é o contemporâneo"). Vamos abordar a Vida de Alcebíades, escrita pelo prosador de Queroneia para

^virginiarb@yahoo.com.br 
contemplar, de outro ângulo, o da prática, o que seja a noção filosófica do "cuidado de si" (epiméleia heautô̂) desenvolvida n'A Hermenêutica do sujeito de autoria de Michel Foucault. $\mathrm{O}$ texto escolhido para análise não tem o prestígio do diálogo Alcebíades I de Platão, tema das aulas iniciais do mestre francês, nem a beleza literária de outra obra do famoso filósofo ateniense, o Banquete, na qual também comparece como personagem o belo filho de Clínias. Vida de Alcebíades nem sequer tem a forma apelativa que, por natureza, traz um diálogo usualmente, ao lançar mão do dinamismo episódico e eventual de um bate-papo e dos recursos da linguagem dramática (o discurso direto e a alternância de pessoas que falam, por exemplo) que, evidentemente, atraem a atenção do leitor-ouvinte para o desenvolvimento da ação. Vida de Alcebíades, no sentido do apelo àquele ao qual se dirige, está em desvantagem quando comparada ao diálogo, que se constitui como um instantâneo tirado de uma conversa da qual nos sentimos convidados a participar. Entretanto, Plutarco leva vantagem em outro aspecto, pois, se escolheu observar Alcebíades e seu comportamento através de um gênero menos dinâmico, mais narrativo, um gênero ainda incipiente no século primeiro, a saber, a biografia, logrou com isso envolver o leitor em uma trama romanceada, divertida e que se pretende real e histórica.

Seu texto já segue os princípios básicos do gênero biográfico e resulta em uma narrativa saborosa engendrada "pela conjunção da teoria [do texto literário na época helenística] e da ficção e pelo teor documental e simbólico do objeto de estudo." Da mesma forma, sua abordagem histórica dessa personagem canonizada pela tradição "procura igualmente apontar detalhes biográficos, até então vistos como insignificantes ou censurados, com o objetivo de remodelar o perfil da pessoa escolhida como objeto de análise. "' O texto de Plutarco, portanto, "(...) se mantém no limite entre a confissão naturalizada da experiência do autor e a sua reelaboração imaginária (...)."3 Tomando, mais uma vez, de empréstimo as palavras e reflexões de Eneida Maria de Souza, ao refletir sobre a crítica biográfica, diremos que Alcebíades recebe, em Plutarco

${ }^{1}$ Cf. Souza, Eneida Maria. Notas sobre a crítica biográfica. In: Crítica Cult. Belo Horizonte: Editora UFMG, 2002. p. 112.

${ }^{2}$ Cf. Souza, op. cit., 2002. p. 117.

${ }^{3}$ Cf. Souza, op. cit., 2002.p. 117. 
ao mesmo tempo, tratamento distanciado por parte do crítico [no nosso caso, o biógrafo grego] e uma aproximação interpretativa, relacionada ao maior ou menor grau de inserção no sujeito no discurso escrito. Essa inserção do intelectual no texto por ele assinado responde, de certa forma, por uma abertura enunciativa, considerando-se que o sujeito se posiciona tanto como indivíduo quanto como representante de um determinado grupo. ${ }^{4}$

De fato, estamos aqui a encarar Plutarco como membro do corpo sacerdotal de Delfos, com responsabilidades junto à coletividade, e como autor contumaz de textos que abordam vidas exemplares (escolhidas por motivos de êxito total ou absoluto malogro dos protagonistas).

Alcebíades, nosso foco, aparece no corpus plutarquiano como protagonista em Vida de Alcebíades e divide o palco com Coriolano na Comparação entre Alcebiades e Coriolano.

O que nos parece curioso, no entanto, o que nos moveu a esta fala é que essas obras de Plutarco não são nem mesmo mencionadas na Hermenêutica do sujeito, embora o estudioso francês sem dúvida as conhecesse. Por que Foucault emudece diante da vida transbordante e efervescente do discípulo amado de Sócrates? Pensamos que, de fato, a Foucault não interessa o Alcebíades de carne e osso; afeta-o, antes, a representação deste no discurso de Sócrates para com seu discípulo.

Embora seja assim, Alcebíades e Plutarco, personagens históricas da Grécia antiga e helenística, repetimos, figuram inúmeras vezes nas cerca de setecentas páginas da edição brasileira da compilação escrita das aulas do curso oferecido por Foucault nos anos de 1981 e 1982 no Collège de France. Além de uma rápida citação da coletânea Apotegmas (p. 42, 53 nota 8), ditos célebres de personagens influentes reunidos a partir de várias fontes e dedicados ao imperador Trajano, e de alguns registros gerais, sem referência a qualquer passagem específica (p. 193, p. 267, 281, 515), Foucault se concentra apenas em um gênero de textos anódinos da escrita do moralista grego, uma espécie de autoajuda que nos legou a Antiguidade. Desse modo ele cita o diálogo $O$ daímon de Sócrates (p. 61, 62, 78, nota 11, p. 280 nota 54, p. 523, 530 nota 31), diversos tratados, como Preceitos de Higiene (p. 119, 131); Como distinguir o bajulador do amigo (p. 224, 452, 473 nota 3); Da curiosidade (p. 268-269, 279 notas 42, 43, 47, 48, 49 e 50; p. 280 nota 51, 53, 55); Da escuta (p. 402, 403, 404, 423 nota 3 e 4, p. 424 nota 7), Sobre a tagarelice (p. 410, 411, 412,

${ }^{4}$ Cf. Souza, op. cit., 2002. p. 117. 
425 notas 18, 20, 21); Sobre a tranquilidade da alma (p. 434, 435, 446 nota 17 , p. 565, 566, 567, 569, 576 nota 13, 14, 15, 577 nota 22); Do controle da cólera (p. 452, 453, 474 nota 5, 522-523, 530 nota 30); a Consolação a Apolônio (p. 225, p. 229, nota 18, 570, 577 nota 29 ) e, por fim, faz duas incursões nas chamadas Vidas: uma na Vida de Demóstenes, (2006 p. 229, nota 14), outra na Vida de Péricles (2006 p. 290, 299 nota 15), o tutor de Alcebíades.

Sendo desta maneira, uma pergunta, em nós, não se cala: por que, n'A Hermenêutica do Sujeito, Foucault silencia quanto ao Alcebíades de Plutarco? Melhor, por que ele não dá voz ao Alcebíades do educador grego? Não vamos respondê-la; não pretendemos desvendar os propósitos de Foucault, nem, repetimos, conhecemos o mestre para tanto. Todavia queremos observar o texto silenciado e tentar perceber os incômodos que sua ausência gerou para o nosso entendimento do "cuidado de si" investigado por Foucault no curso A Hermenêutica do sujeito.

Pensávamos inicialmente que a escolha da referência básica deviase ao formato dado por Platão para nos apresentar o descendente de Ájax juntamente com Sócrates. Julgávamos que a escolha seria advinda do dinamismo que provoca uma conversa filosófica de caráter eróticoinstrutivo. Todavia essa hipótese cai por terra quando consideramos o extenso uso da obra plutarquiana no decorrer do curso ministrado.

Longe de nós a ideia de que o curso de 1982 devesse esgotar as fontes de referência acerca do belo ateniense; escolhas são necessárias e os testemunhos sobre o protegido de Péricles são numerosos: além de Plutarco, Platão, Tucídides, Xenofonte, Diodoro da Sicília, Cornélio Nepos, Andócides, Isócrates, Lísias, Aristófanes, Eurípides e Pausânias, podemos supor sem equívoco tantos outros que desconhecemos até o presente momento.

Não; o problema não é este. A questão perturbadora no silêncio sobre o Alcebíades de Plutarco é que esta obra, segundo a tradição, foi escrita por um neoplatônico, sacerdote em Delfos, o lugar de origem, segundo o próprio Platão (no Alcebíades I, 124a-b; no Filebo 48d-d; no Hiparco 228c; nas Leis 11, 923a), da exortação pítica discutida por Foucault, "conhece-te a ti mesmo" e de seu suplemento, a epiméleia heautoû ou o "cuidado de si" que ademais, como afirma o autor da Hermenêutica do sujeito,

acompanhou, enquadrou, fundou a necessidade de conhecer-se a si mesmo não apenas no momento do seu surgimento no pensamento, na existência da personagem de Sócrates. [...] a epiméleia heautô̂ (o cuidado de si e a regra que lhe era associada) não cessou de constituir 
um princípio fundamental para caracterizar a atitude filosófica ao longo de quase toda a cultura grega, helenística e romana. ${ }^{5}$

E ainda, em outra passagem:

A necessidade de por em exercício uma tecnologia de si para ter acesso à verdade é uma ideia manifestada na Grécia arcaica e, de resto, em uma série de civilizações, senão em todas, por certo número de práticas (...).

As práticas a que Foucault se refere são os ritos de purificação, a reflexão, a anacorese, a prática de resistência etc. Mas, além do motivo perturbador de ignorar a opinião de um délfico, que ele bem conhece, sobre a aplicação de uma sentença délfica na personagem que materializa a "não-prática do cuidado de si" na literatura - o que parece bastante estranho - há que se pensar também em outro provável e significativo embaraço que se origine, talvez, no fato de que n'A Hermenêutica do sujeito o mestre opte por lidar com conceitos e não com personalidades. Talvez a escolha se dê porque conceitos sejam mais disciplinados, ao passo que personalidades como as de Alcebíades sejam transbordantes, extrapolantes, monstruosas. Diante dele - pessoa viva que foi - a natureza, as leis e o próprio Foucault se calam. Assim, o filósofo opta por uma versão abstrata de pessoas enquanto que o homem das letras busca exibir a experiência humana de seu personagem vivendo-a em sua particularidade, em sua singularidade e integridade individual.

A postura é de fato uma maneira de ser platônica, segundo Martha Nussbaum. ${ }^{7}$ Consequentemente, seria possível acreditar que Foucault procure antes contemplar a perfeição do "cuidado de si" como um postulado e que se esqueça de observar o efeito de sua ausência; em outros termos, ele vê em Alcebíades um motivo para discutir um conceito e se esquece e a forma reflexiva do verbo permite admitir que, ao fazer isso, ele, conscientemente, despreza a valia de examinar o homem - se esquece, repito, do indivíduo singular que o grego foi, um sujeito acometido da imprudência do "não cuidado de si". É portanto nessa perspectiva que vamos contemplar a figura que se movimenta no texto plutarquiano.

${ }^{5}$ Cf. Foucault, M. A Hermenêutica do sujeito. Trad. Márcio Alves da Fonseca e Salma Tannus Muchail. São Paulo: Martins Fontes, 2006. p. 11-12.

${ }^{6}$ Cf. Foucault, op. cit., 2006. p. 59-60.

${ }^{7}$ Apoiada em reflexões de Gregory Vlastos, Martha Nussbaum, em capítulo da obra A Fragilidade da bondade intitulado "A fala de Alcebíades: uma leitura do 'Banquete", assume um contraste entre a metodologia do filósofo e a do homem de letras. 
Decerto, não se pode ignorar o fascínio da celebridade. As biografias, infalíveis nas listas dos livros mais vendidos, e todo um mercado de revistas de fofocas e tabloides e sites direcionados a isso não nos deixa mentir: a curiosidade indiscreta está em todos. No caso do texto que aqui debatemos, o que fortemente nos seduz, entretanto, mais que o interesse pela vida alheia, é a visão do sacerdote de Apolo, um disciplinador de si e dos outros; o modo como ele recebe a máxima délfica "cuida de ti mesmo" e que conexões ele faz entre os atos praticados e os relacionamentos vividos por essa personagem tão ambígua e controvertida da famosa democracia ateniense.

Priscila Vieira ${ }^{8}$ indica que o cuidado de si em Plutarco adquire características diferentes das que apresenta Platão, quais sejam, o governo de si para governar os outros e, por conseguinte, das que aponta Foucault ao estudar o filósofo ateniense. Cuidar de si para Plutarco não será mais uma prática para exercer bem a vida política: pelo contrário, cuidar de si é desviar-se da vida política; é não buscar a lisonja, é entendêla como um risco moral, é resistir aos apelos exteriores. Seria Plutarco um precursor da "resistência" interna do sujeito?" Não chegamos a afirmá-lo. Digamos somente que, no relato plutarquiano, que se estrutura no formato "vida de", temos um enredo prático e benfeito que propõe, por meio de certas ligações percebidas à distância de cinco séculos, um Alcebíades que foi gerado pela pólis e que teve um princípio e um fim com ela relacionados, enquanto os diálogos platônicos (Alcebíades I e Banquete) o focalizam de forma fugaz, na volubilidade e volatilidade de um flerte. Nosso Alcebíades está citado ainda na Poética de Aristóteles $(9,1451 \mathrm{~b} 10)$ igualmente como uma efeméride, um fato histórico irrepetível e circunscrito ao particular. Em Plutarco, todavia, ao contrário do que se esperava, o singular se instaura como universal e paradigmático. Essa inversão é gerada pela genialidade do escritor, que alia indivíduo e contexto numa única matéria. $O$ tratamento que se lhe dá ao descrevê-lo é igualmente uma análise da cidade de Atenas do chamado período clássico e de seus frutos humanos, os transgressores e os disciplinados.

Inicialmente, como afirmamos, Plutarco opta por um gênero de narrativa, a nosso ver, mais complexo que o diálogo no que tange à

${ }^{8}$ Cf. Vieira, P. P. A escrita de si e a parrhesía, verdade e o cuidado de si em Michel Foucault. In: Rago, M. (Org.). Revista aulas, Dossiê estéticas da existência. Campinas, n. 7, p. 187-204, 2010.

${ }^{9}$ Cf. Foucault, M. L'éthique du souci de soi comme pratique de la liberté. In: Dits et écrits. Paris: Gallimard, 1994. Vol IV, p. 708-729. 
veridicidade do assunto desenvolvido, que abrange todo o período de uma vida, devendo apresentar coesão e coerência temporal, mas que simultaneamente usa dos recursos da ficção.

Samuel Johnson no Rambler (Johnson 1962a [1750]) e no Idler (Johnson 1962b [1759]), Virginia Woolf nos The new biography (1927) e The art of biography (autores citados apud Monk, 2007, p. 528-570) e mais recentemente Arnaldo Momigliano (no The development of Greek biography, 1993) - este último especificamente para a biografia grega - todos estes apontam para a complexidade do gênero que se situa no âmbito da história e simultaneamente da literatura. De acordo com Woolf, ${ }^{10}$ um biógrafo não pode simplesmente inventar seu personagem, pois documentos e testemunhos estão à mão para desmenti-lo; tampouco pode, livremente, criar situações já que cada sentença sua é passível de verificação. $O$ procedimento que lhe cabe é de seleção e composição de relações. Nestes termos uma biografia requer perícia narrativa para engajar o leitor tal como se se tratasse de um romance. ${ }^{11}$ Nela não se busca, no entanto, uma acumulação de fatos, mas o estabelecimento de vínculos que garantam uma ordem no emaranhado de ações do biografado, de modo que a vida de um outro, vista por fora, possa atingir sua essência mais recôndita, o que Platão e Foucault chamam de alma. São palavras do mestre francês para definir o "cuidado de si":

Ocupar-se não com o corpo, mas ocupar-se com sua alma, com sua alma enquanto ela é sujeito de ação e se serve mais ou menos bem de seu corpo, de suas aptidões, de suas capacidades, etc.

(...)

Creio que temos aí (aquilo que, parece-me, devemos reter) o que define a posição do mestre na epiméleia heautô̂ (o cuidado de si). Pois o cuidado de si é, com efeito, algo que como veremos, tem sempre necessidade de passar pela relação com o outro que é o mestre. Não se pode cuidar de si sem passar pelo mestre, não há cuidado de si sem a presença de um mestre. ${ }^{12}$

\footnotetext{
${ }^{10} \mathrm{Cf}$. Woolf, V. The art of the biography. (digitalizado no "Projeto Gutenberg": http:// gutenberg.net.au/ebooks02/0200771.txt): The biographer could not invent her [queen Victoria], because at every moment some document was at hand to check his invention. And, in writing of Victoria, Lytton Strachey submitted to the conditions. He used to the full the biographer's power of selection and relation, but he kept strictly within the world offact. Every statement was verified; every fact was authenticated.

${ }^{11}$ Cf. Monk, R. Life without theory. Biography as an exemplar of philosophical understanding. Durham, NC: Duke University Press, 2007. p. 536.

${ }^{12}$ Cf. Foucault, op. cit., 2006. p. 73.
} 
Porém de novo o desconforto emerge. Se Foucault estabelece um conceito filosófico, o biógrafo de Alcebíades é quem procede mais como Sócrates e quem pratica de maneira bem adequada - e anacronicamente, é verdade - uma relação de mestre observador para com Alcebíades e para com seus leitores.

Mas isso é útil? Para que nos serve pensar sobre personalidades e autores que distam de nós muitos séculos e muitos mares? Alcebíades está morto, não se modificará mais...

Convenhamos que utilidade alguma teria o relato se, para Plutarco, Alcebíades fosse somente um indivíduo... Indivíduo de fato ele o é, mas, na escritura de Plutarco, além de o ser em sua integridade singular, Alcebíades é ao mesmo tempo metáfora da monstruosidade da cidade e da democracia ateniense, ambas belíssimas, exageradas, variadas, formas espontâneas e brutais que permitem a cada um ser o que lhe parece ser. Então, observar Alcebíades como Atenas é útil? Tampouco. Atenas já não se rege pela problemática democracia do século V a.C. - a Atenas de Alcebíades está morta, não se modificará mais. Ora, deixemos claro: não buscamos, parodiando Agamben, o filósofo do Homo sacer, um outro tempo, não pretendemos agir como "um nostálgico que se sente em casa mais na Atenas de Péricles" ou na Paris de Foucault mais do que na cidade e no tempo que nos foi dado viver. ${ }^{13}$ Eis, de fato, como argumenta o pensador italiano:

Os historiadores da literatura e da arte sabem que entre o arcaico e o moderno há um compromisso secreto, e não tanto porque as formas mais arcaicas parecem exercitar sobre o presente um fascínio particular quanto porque a chave do moderno está escondida no imemorial e no pré-histórico. Assim, o mundo antigo no seu fim se volta, para se reencontrar, aos primórdios; a vanguarda, que se extraviou no tempo, segue o primitivo e o arcaico. É nesse sentido que se pode dizer que a via de acesso ao presente tem necessariamente a forma de uma arqueologia que não regride, no entanto, a um passado remoto, mas a tudo aquilo que no presente não podemos em nenhum caso viver e, restando não vivido, é incessantemente relançado para a origem, sem jamais poder alcançá-la. Já que o presente não é outra coisa senão a parte de nãovivido em todo vivido, e aquilo que impede o acesso ao presente é precisamente a massa daquilo que, por alguma razão (o seu caráter traumático, a sua extrema proximidade), neste não conseguimos viver.

\footnotetext{
${ }^{13}$ Cf. Agamben, G. O que é o contemporâneo? e outros ensaios. Trad. Vinícius Nicastro Honesko. Chapecó: Argos, 2009. p. 59.
} 
A atenção dirigida a esse não-vivido é a vida do contemporâneo. E ser contemporâneo significa, nesse sentido, voltar a um presente no qual jamais estivemos. ${ }^{14}$

A utilidade de nos fixar sobre Alcebíades como uma metáfora de Atenas, a utilidade de nos fixar no belo moço em contraponto com as reflexões de Foucault é a de perceber que o político e sua cidade aderiram irrevogavelmente a nós. De forma impressionante eles coincidem com nossa época que faz baliza entre a escolha pessoal e subjetiva e a compulsão. De tal modo Alcebíades, Platão, Plutarco e Foucault se reatualizam nela que eles se tornam chaves que abrem portas para entendimento de nossa própria vivência e nossa busca de felicidade. Sim, agora pensamos com Aristóteles na busca da virtude, areté, para alcançar a eudaimonía.

Ocorre que pela urdidura do texto plutarquiano Alcebíades e Atenas são indivíduo e povo, sujeito governante e sujeito governado, polites e dêmos que ao morrerem não foram, pelo menos nos moldes de Sólon, felizes. E é assim que, pela alegoria, o que era particular se torna universal e nos atinge. Trata-se, portanto, de um texto filosófico escrito de maneira simbólica e com o intuito de apresentar ideias e concepções intelectuais acerca da educação de si e do outro com seus resultados. Como se dá tudo isso?

Abro um parêntese para dizer que essa nossa leitura se apoia na teoria de Ray Monk, ${ }^{15}$ que hipotetiza ser a biografia um gênero filosófico em duas perspectivas: abriga a filosofia que há por detrás do narrado e a filosofia como um gênero literário propriamente dito. Sintam-se, portanto, justificados os leitores ocultos da vida dos famosos...

Plutarco escreve seu texto no final de uma longa tradição de histórias acerca do garboso rapaz da cidade de Atenas. Estruturalmente a Vida de Alcebíades segue um esquema rígido de todas as demais biografias escritas no mundo antigo: narra-se a origem da personagem - um ancestral de Eurísaques, filho de Ájax - da sua família, aparência, estilo de vida, costumes, mestres e processo de aprendizado. ${ }^{16}$ Episódios de infância e ditos anedóticos são arrolados; segue-se a enumeração de uma série de atos e dessa forma vai-se revelando, paulatinamente, pela apresentação das ações realizadas do biografado, o seu caráter. Nesse

\footnotetext{
${ }^{14}$ Cf. Agamben, op. cit., p. 70.

${ }^{15}$ Cf. Monk, op. cit., p. 527-570.

${ }^{16}$ Cf. Berger, K. As formas literárias do novo testamento. São Paulo: Edições Loyola, 1998, p. 99.
} 
percurso agradável e pitoresco o autor fará uma interpretação do processo educativo e formativo do sujeito e da cidade que o cria e denunciará um problema de fundo, de base: a integração do circundante, a cidade e do cidadão. No caso do filho de Clínias: o pobre menino rico nunca foi, verdadeiramente, educado (neste aspecto Plutarco e Foucault coincidem, ver por ex. p. 56 d'A Hermenêutica do sujeito).

De que padece o mancebo? Segundo Plutarco (Vida de Alcebíades, \6), citando Tucídides, Alcebíades padecia de uma paranomia para com seu próprio corpo, condição facilmente detectável pela sua maneira de viver. Esta paranomía, no decurso da narrativa, consistirá numa vida devotada à luxúria, numa falta de firmeza moral, numa ambição desmedida, no abuso de virilidade e de efeminação e num estilo de vida arriscado, perdulário, negligente, de violência incontida. Percebe-se naturalmente que paranomía em Plutarco iguala-se a um desleixo com o "cuidado de si".

Mas, observando de perto, esse rapaz assim descrito é nada mais nada menos que Atenas e essa Atenas é nada menos que qualquer outra cidade e mesmo qualquer outro cidadão; daí o grande interesse da pequena biografia de Alcebíades narrada por Plutarco.

A hipótese não é despropositada para a literatura do mundo antigo. Tomemos um outro autor também muito abalado com a figura do jovem ateniense em questão, Tucídides, que se ocupa em várias passagens do nome e pesoa de Alcebíades. Porém estamos falando da metáfora segundo a qual Alcebíades é Atenas. Carolyn Dewald afirma que: ${ }^{17}$

Thucydides admires and celebrates imperial Athens - and also clearsightedly narrates the stupidities and misjudgments that would eventually defeat it. In terms of structure, he can change his most basic narrative habit and abandon his earlier use of narrative parataxis

\footnotetext{
${ }^{17}$ Cf. Dewald, C. Thucydides' war narrative. Berkeley/Los Angeles/London: University of California Press, 2005, p. 21: "Tucídides admira e celebra a Atenas imperial - ele também narra, de forma clarividente, as estupidezes e falsos julgamentos que poderiam eventualmente arruiná-la. Em termos de estrutura [sintática], Tucídides é capaz de mudar seus hábitos narrativos básicos e abandonar o uso inicial da parataxe narativa quando ela não se faz mais adequada para a tarefa de registrar a complexidade interconectante de eventos em progresso no fim da Guerra do Peloponeso. À medida que ele costura, tão acuradamente quanto é possível, as múltiplas vozes e fios interpretativos que tecem os vinte e sete anos de guerra, sua voz autoral continua diligentemente a negociar com muitas outras vozes que encontramos na História" (minha tradução).
} 
when it is no longer adequate to the task of registering the interconnecting complexity of developing events late in the Peloponnesian War. As he weaves together as accurately as he can the multiple voices and interpretive threads that make up the twentyseven-year war, his own authorial voice continues attentively to negotiate the many other human voices we encounter in the History.

Se assim é com Atenas, assim também será com Alcibíades em Plutarco. Nessa perspectiva (e entendo que também na perspectiva foucaultiana), construir uma cidade, construir uma pessoa - em presente vivido - ou até uma personagem é negociação de valores, escolhas, objetivos; é trama tecida de forma complexa com fios próprios e com fios de vozes que cercam, formam, aplaudem, censuram, rejeitam.

Desse modo, se Tucídides nos mostra um quadro em que os eventos em Atenas não são fenômenos isolados, ${ }^{18}$ se ele nos convence de que forças múltiplas podem levar a cidade a um cataclismo definitivo; se nos mostra que Alcebíades, mesmo no exílio, é significante perigosamente significante - na mesma guerra e se, finalmente, ele atribui ao nosso jovem herói a responsabilidade exclusiva pela derrocada da Sicília, ${ }^{19}$ então Alcebíades e Atenas ficarão para sempre, em nosso imaginário, atrelados.

Resta justificar, rapidamente, pois esse é nosso interesse, o uso da metáfora em Plutarco e em Vidas. Para isso, recordamos a abertura da Vida de Fócion $(742,1){ }^{20}$ quando o mestre de Queroneia menciona, como se de pessoa se tratasse, a dignidade e caráter de Atenas e argumenta acerca da justeza de conceder-lhe perdão já que a cidade, nessa altura, após a Guerra do Peloponeso, estaria administrando os restos de um naufrágio do Estado. ${ }^{21}$ Nessa introdução temos, com segurança, a metáfora da nau do Estado e a atribuição, em prosopopeia, de marcas pessoais (dignidade e caráter) para a cidade de Alcebíades.

\footnotetext{
${ }^{18}$ Cf. Dewald, op. cit. p. 151; cf. ainda Tucidides. Historia de la guerra del Peloponeso. Madrid:Alianza Editorial, 2008, VI, 8; VIII, 109.

${ }^{19}$ Cf. Dewald, op. cit. p. 153; cf. ainda, Tucidides, op. cit., VI, 88; VI, 93.

${ }^{20}$ Cf. Plutarco. Vida de Foción. Introducción, traducción y notas de Carlos Alcalde Martín. Madrid: Ediciones Clásicas, 2001.

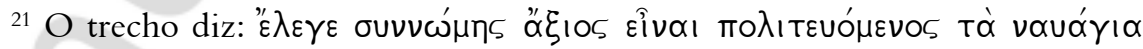

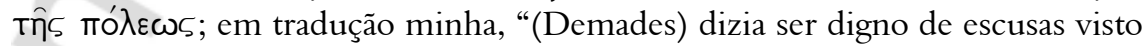
que administrava os naufrágios da cidade". O texto grego utilizado foi Plutarch's Lives. English translation by Bernadotte Perrin. Cambridge, Mass./ London: Harvard University Press, 1919. Vol. VIII.
} 
Já na Vida de Alcebíades, a estratégia é a seguinte: Plutarco se debruça sobre sua personagem e elenca detalhes que deixam aflorar vícios e virtudes de forma que cada ação apresentada para retratar o sujeito seu tom de voz, o estilo de fala, o modo de andar - seja fundamental para fazer alcançar sua alma e seu entorno e, deste modo, perceber como ela está sendo tratada por ele próprio e pelos circunstantes. Alcebíades, cidadãos atenienses e Atenas formam um bloco metafórico que apresenta o filho de Clínias como núcleo. Veremos o nosso rapaz, mal formado, com defeitos pequenos e grandes, mas sempre aliciante; a começar ele é incapaz de pronunciar o som [r], substituindo-o sempre pelo [1]. Em palavras de Plutarco:

Então, da beleza de Alcebíades, igualmente, nada é preciso dizer exceto que foi exuberante em cada ano e idade seja como criança, adolescente e depois como homem feito; agradável e atraente de corpo mantinha-se sempre.

(...)

Seu lambdacismo convinha em sua voz e dava a sua fala um encanto acabado e sedutor.

Neste primeiro exemplo pode-se observar sem esforço uma certa tolerância de todos para com os defeitos e falhas do belo Alcebíades. Plutarco, aliás, vai insistir neste ponto e relatará inúmeros episódios os quais, nas entrelinhas, demonstrarão o perigo de tal comportamento. No $\ 8$, ele arrasta sua mulher - que o havia abandonado por causa de sua vida licenciosa - pelas ruas de Atenas. Nesse trecho o autor comenta imediatamente, como se isso não tivesse importância: "aquela violência ninguém considerou ilegal ou brutal..." Há também outro trecho em que vemos Péricles acobertar uma fuga do menino para um encontro amoroso com Demócrates; em outra ocasião contemplamos uma violência cometida contra o professor dos poemas homéricos e a invasão da casa de Anito com a apropriação indevida de seus vasilhames de ouro e prata - na lei da polis, um crime de morte -; enfim, contravenções para as quais Plutarco comenta: "Desde cedo mimado, no convívio de seus aduladores, que o fechavam à influência de quem o repreendesse e educasse, pôde, não obstante, devido a sua boa índole, compreender a Sócrates, a quem se apegou...” (\$ 4), o único, segundo Plutarco acrescenta, que o fazia chorar e arrepender-se de seus atos. Contudo, no $\mathbb{} 7$, conta o biógrafo que, adolescente ainda, o jovem engajou-se juntamente com Sócrates na expedição contra Potideia. Na refrega, Alcebíades cai ferido. Sócrates o protege e salva. Retornando para a cidade, um prêmio de bravura seria dado aos heróis. Por certo o prêmio 
caberia a Sócrates que, no entanto, de comum acordo com os generais e em função da posição social do rapaz, confere-o ao fracassado.

Coroa e panóplia não ao valente, mas ao mais belo! O episódio é excelente para expor a perversidade de uma educação indulgente, tolerante em excesso e conivente. Plutarco informa que tal medida foi tomada para despertar no novo combatente a ambição pelas honras dadas pelo heroísmo. Mas, nisso tudo, em nosso ponto de vista, quem perde é o belo e pobre menino rico. A passagem justifica até a suspeita levantada por Kitto: ${ }^{22}$ seria Sócrates, como educador de Alcebíades, absolvido hoje? Acrescentamos neste ponto uma outra reflexão: como o mestre Sócrates está cuidando do seu discípulo? E mais, como Plutarco, ao introduzir tal passagem na narrativa, está cuidando de seus leitores? Um segundo exemplo: Alcebíades tem uma personalidade ambígua e age como guerreiro e ao mesmo tempo como covarde: em luta com um colega, imobilizado pelo adversário, salva-se mordendo o adversário, que grita: "Alcebíades, mordes como uma mulher!". Não obstante, o futuro grande general arrogantemente responderá: "Mulher não, rapaz, como um leão!" Leão que levantará nos endóxoi, nos ilustres atenienses, a suspeita de um caráter tirânico. Caráter que o levará ao exílio, e que no exílio em Esparta o tornará inimigo de Atenas, amante da rainha e pai de um filho dela.

Pensemos juntos: o que leva Plutarco a desenrolar tantas historietas, algumas anedotas e tantos comentários paralelos às situações narradas senão a descrição de uma cultura que se baseia no controle e no descontrole de si, na transgressão? Uma cultura que se vê tragicamente punida pelos seus anseios desmedidos e inconsequentes? Uma cultura que ama e rejeita o diferente?

Cremos que, desenhando dessa forma o amado de Sócrates, Plutarco faz dele uma personagem trágica que viveu uma vida cheia de

\footnotetext{
${ }^{22}$ Cf. Kitto, H. D. F. Os gregos. Coimbra: Arménio Amado, 1990. p. 254-255.

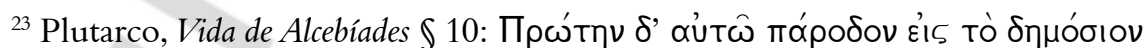

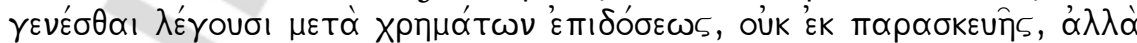

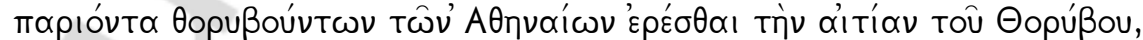

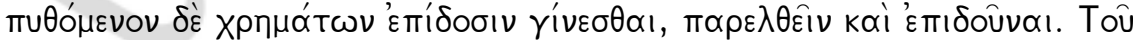

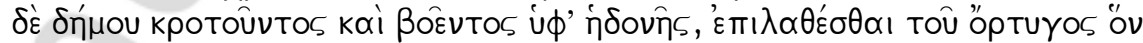

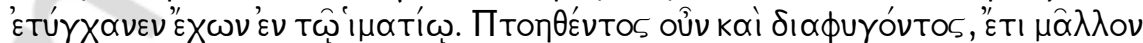

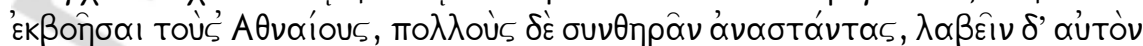

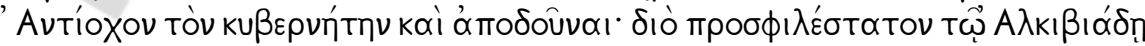

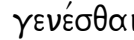


grandiosidades, reveses, contradições, apogeus e quedas $(\mathbb{\$} 2)$. Tal qual os protagonistas trágicos, sua entrada na vida pública se dá como um espetáculo e sua saída é catastrófica.

Ouçamos o délfico:

Contudo, para ele, a estreia na cena pública dizem ter sido depois duma doação de bens - não por projeto - mas quando, passando por atenienses em algazarra pergunta a causa do alarde e é informado de que si tratava da doação de riquezas.

Ele entrou e contribuiu e, no que o povo bateu palmas e, de prazer, ovacionou, Alcebíades esqueceu-se da codorniz que - por acaso levava no manto... Ela assustada se põe a fugir, então, ainda mais os atenienses gritaram e muitos, de pé, se põem a caçar...

Aí, Antíoco, o piloto, agarra-a e entrega-a. Com isso tornou-se o "queridinho" de Alcebíades. ${ }^{23}$

Assistindo à cena descrita como a um filme, vemos com que facilidade o aspirante político se esquece de seus cuidados. Jacqueline de Romilly ${ }^{24}$ acerca do passo informa: "Para que ele pudesse assomar à tribuna, era necessário que já não fosse criança; mas sabe-se que aves domésticas como galos ou codornizes eram muitas vezes presentes de namorados". ${ }^{25}$ Este menino que quer governar, que por encantos diversos logra o apoio de todos, esse menino estava ainda na idade de ganhar presentes e nessa fase ele nem cogita sobre quaisquer cuidados, quer com o corpo, com os amantes ou, menos ainda, com os cuidados para consigo mesmo.

Mas Alcebíades é fruto de uma estrutura aristocrática que acabou por representar a gloriosa cidade de Péricles, a qual foi arruinada por um seu protegido.

Ao fim da narrativa, no parágrafo trinta e nove, ei-lo: exilado, numa aldeia frígia, longe do poder, em casa de Timandra, uma cortesã, ele será alvejado. "Os enviados para matá-lo não se atreveram a entrar. Cercaram a casa e atearam fogo". Alcebíades foge e ao sair recebe no corpo dardos e flechas de rivais injuriados.

\footnotetext{
${ }^{24}$ Cf. de Romilly, J. Alcebíades ou os perigos da ambição. Trad. Roberto Cortes de Lacerda. Rio de Janeiro: Ediouro, 1996. p. 45.

${ }^{25}$ Aristófanes, As aves, v. 707.

${ }^{26}$ Plutarco, Vida de Alcebíades. In: Vidas. Trad. Jaime Bruna. São Paulo: Editora Cultrix, [s.d.], §39, p. 137.
} 
O que podemos concluir? O principezinho da Atenas, aquele que Pausânias diz ter sido pintado entre Diomedes e Ulisses, entre Orestes e Aquiles, aquele que conta Plutarco ter sido representado no dorso do leão de Nemeia, este Alcebíades foi um descuidado. Amou, singularmente, a Sócrates, mas este amor não o salvou. Sócrates buscava o Belo em Alcebíades e não tinha olhos para a beleza humana de Alcebíades, o jovem ao qual ninguém era indiferente, aquele que era admirado por todos porque foi excessivo em tudo.

Plutarco interpretou de modos variados as atitudes de seu protagonista. Parece-nos que ele propõe em seu relato uma reorientação para a Cidade - e escrevo cidade com letra maiúscula para indicar todo e qualquer espaço em que o homem habita... - Foucault comenta este propósito de Plutarco ao discutir o tratado Da curiosidade (p. 268). A impossibilidade de exercer o poder, apesar de todos os requisitos para tal, adveio da falta de controle de si (Foucault reflete acerca desse comportamento quando aborda o tratado Da cólera, p 453). Com efeito, Alcebíades, despercebido, mata seu futuro; a pólis despercebida, também mata seu futuro e, na alegoria antes comentada, o homem, em seu "descontrole de si", há de matar o seu e o nosso futuro.

Feliz e bem-vindo seja o biógrafo que nos mostrou isso; feliz e bem-vindo seja o filósofo que teorizou o cuidado de si. É preciso lembrar sempre que "aquele que não se ocupa consigo é um stultus", ${ }^{27}$ mas que o ocupar-se consigo se faz em uma relação com o outro, uma relação que se dá na esfera do prático e do teórico. Afinal, "[a] verdade jamais é dada ao sujeito por um simples ato de conhecimento". ${ }^{28}$ Nesse ponto, comparando o estudioso francês e Plutarco, observamos que Foucault, como Platão, teorizou a experiência filosófica de Sócrates; Plutarco, por sua vez, contemplou Alcebíades e cuidou de cuidar de si e dos seus discípulos a partir do belo contraexemplo ateniense.

Finalizando, encerramos agradecidos pela oportunidade de nos relacionar, por grandes e bons momentos, em trato de amizade literária ${ }^{29}$ com Foucault e Plutarco. Se Foucault emudeceu e não contemplou a vida de Alcebíades, não importa. Importa sim fraturar o tempo, olhar Platão, Plutarco e Foucault como feridas abertas que supuram o monstruoso, o terrível, o sublime que transborda de todos nós. Dessa forma, nos fazemos seus contemporâneos e eles se tornam o mesmo para nós.

\footnotetext{
${ }^{27}$ Cf. Foucault, op. cit., 2006. p. 565.

${ }^{28}$ Cf. Foucault, op. cit., 2006. p. 19.

${ }^{29}$ Cf. Souza, op. cit., 2002. p. 117.
} 


\section{Referências}

AGAMBEN, G. O que é o contemporâneo? e outros ensaios. Trad. Vinícius Nicastro Honesko. Chapecó: Argos, 2009.

ARISTÓFANES. As aves. In: Le commedie. Traduzione, testo greco, appendice critica a cura di Benedetto Marzullo. Roma: Grandi Tascabili Newton, 2003. p. 483-451.

BERGER, K. As formas literárias do novo testamento. Trad. Fredericus Stein. São Paulo: Edições Loyola, 1998.

DEWALD, C. Thucydides' war narrative. Berkeley/ Los Angeles/ London: University of California Press, 2005.

EVANS, N. Civic Rites. Democracy and religion in ancient Athens. Berkeley/ Los Angeles: University of California Press, 2010. p. 131-169.

FOUCAULT, M. A Hermenêutica do sujeito. Trad. Márcio Alves da Fonseca e Salma Tannus Muchail. São Paulo: Martins Fontes, 2006.

L'éthique du souci de soi comme pratique de la liberté. In: Dits et écrits. Paris: Gallimard, 1994. Vol. IV. p. 708-729.

GIRAUD, J. M. L'Alcibiade de Thucydide et de Xénophon. Mètis. Anthropologie des mondes grecs anciens. Paris: École des Hautes Études em Sciences Sociales, 1998. Vol. XIII, p. 383-400.

KITTO, H. D. F. Os gregos. Trad. José Manuel Coutinho e Castro. Coimbra: Arménio Amado, 1990.p. 253-280.

MOMIGLIANO, A. The development of Greek biography. Cambridge, Mass./ London: Harvard University Press, 1993.

MONK, R. Life without theory. Biography as an exemplar of philosophical understanding. Durham, NC: Duke University Pres, 2007.p. 536.

NUSSBAUM, M. C. A fala de Alcebíades: uma leitura do "Banquete". In:

A fragilidade da bondade. Fortuna e ética na tragédia e na filosofia grega. Trad. Ana Aguiar Cotrin. São Paulo: Editora WMF/ Martins Fontes, 2009. p. 145-175.

PLUTARCO. Alcebíades. Cambridge, Mass./ London: Havard University Press, 1986.

.Vida de Foción. Introducción, traducción. y notas de Carlos Alcalde Martin. Madrid: Ediciones Clásicas, 2001.

.Plutarch's Lives. English translation by Bernadotte Perrin. Cambridge, Mass./ London: Harvard University Press, 1919. Vol. VIII.

de ROMILLY, J. Alcebíades ou os perigos da ambição. Trad. Roberto Cortes de Lacerda. Rio de Janeiro: Ediouro, 1996. 
SOUZA, Eneida Maria. Notas sobre a crítica biográfica. In: Crítica Cult. Belo Horizonte: Editora UFMG, 2002. p. 111-120.

TUCÍDIDES. Historia de la Guerra del Peloponeso. Introducción, traducción y notas de Antonio Guzmán Guerra. Madrid: Alianza Editorial, 2008.

VIEIRA, P. P. A escrita de si e a parrhesía, verdade e o cuidado de si em Michel Foucault. In: RAGO, M. (Org.). Revista aulas, Dossiê estéticas da existência. Campinas, n. 7,p. 187-204, 2010.

WOOLF, V. The art of the biography (acesso em 27 de abril de 2010). < http:// gutenberg.net.au/ebooks02/0200771.txt> 